\title{
HUBUNGAN DERAJAT AKTIVITAS PENYAKIT LUPUS ERITEMATOSUS SISTEMIK BERDASARKAN SKOR MEX-SLEDAI DENGAN KEJADIAN ANEMIA PADA PENDERITA LUPUS ERITEMATOSUS SISTEMIK DI KOMUNITAS ODAPUS LAMPUNG
}

\author{
Rina Kirwiastiny ${ }^{1}$, Ringgo Alfarisi ${ }^{2}$, Hidayat $^{3}$ \\ Ageel Al-Aziz Marjaen ${ }^{4}$
}

\author{
${ }^{1}$ Dosen Progam Studi Fakultas Kedokteran Universitas Malahayati \\ Email : rinakriswiastiny@yahoo.com \\ ${ }^{2}$ Dosen Program Studi Fakultas Kedokteran Universitas Malahayati \\ Email : ringgo_alfarisi@gmail.com \\ ${ }^{3}$ Dosen Program Studi Fakultas Kedokteran Universitas Malahayati \\ Email : hidayatpatklin@yahoo.com \\ ${ }^{4}$ Mahasiswa Program Studi Fakultas Kedokteran Universitas Malahayati \\ Email : agelmnopqrs@gmail.com
}

\begin{abstract}
RELATIONSHIP OF SYSTEMIC LUPUS ERYTHEMATOSUS ACTIVITIES BASED ON MEX-SLEDAI SCORE WITH INCIDENCE OF ANEMIA IN SYSTEMIC LUPUS ERYTHEMATOUS PATIENTS IN THE ODAPUS LAMPUNG COMMUNITY, 2020
\end{abstract}

Background : Systemic Lupus Erytematosus (SLE) is a complex autoimmune disease characterized by the presence of autoantibodies against the cell nucleus and involving many organ systems in the body. Anemia in LES patients varies between chronic disease anemia, hemolytic anemia, blood loss, renal insufficiency, infection, myelodysplasia, and aplastic anemia. What often occurs in LES anemia is due to erythropoesis suppression due to chronic inflammation. Anemia in LES patients is an immune or non-immune disease. Anemia is a nonimmune disease is anemia in chronic disease, iron deficiency anemia, sideroblastic anemia, anemia in kidney disease, anemia indicated by drugs, and anemia secondary to other diseases (eg sickle cell anemia).

Research purposes : This study was to determine the degree of activity of systemic lupus erythematosus based on max-sledai and hemoglobin levels in systemic lupus erythematous patients in the ODAPUS Lampung community in 2020.

Methode :The analytical observational method was used using a cross sectional approach. The research subjects were 30 respondents who used the total sampling technique from members of the ODAPUS Lampung community by conducting MEX-SLEDAl interviews and blood sampling conducted from November 2019 to February 2020. Statistical test used Fisher exact test.

Results: From 30 study subjects, disease activity based on MEX-SLEDAI was above the average of 21 patients (70\%). And the results of blood tests were 18 patients $(60 \%)$ who were not anemia and 12 patients $(40 \%)$ had anemia.

Conclusion : There was a significant relationship between the degree of activity of Systemic Lupus Erythematosus based on the MEX-SLEDAI score and the incidence of anemia with $p$ value $=0.024$ meaning the $p$ value $\leq 0.05$.

Keywords : LES; Incidence of Anemia; MEX-SLEDAI 


\section{INTISARI : HUBUNGAN DERAJAT AKTIVITAS PENYAKIT LUPUS ERITEMATOSUS SISTEMIK BERDASARKAN SKOR MEXSLEDAI DENGAN KEJADIAN ANEMIA PADA PENDERITA LUPUS ERITEMATOUS SISTEMIK DI KOMUNITAS ODAPUS LAMPUNG}

Latar belakang : Systemic Lupus Erytematosus (SLE) merupakan penyakit autoimun yang kompleks ditandai oleh adanya autoantibodi terhadap inti sel dan melibatkan banyak sistem organ dalam tubuh. Anemia pada pasien LES bervariasi antara anemia penyakit kronis, anemia hemolitik, kehilangan darah, insufisiensi ginjal, infeksi, mielodisplasia, dan anemia aplastik. Yang sering terjadi anemia pada LES disebabkan supresi eritropoesis karena inflamasi yang kronis. Anemia pada pasien LES merupakan penyakit imun atau non-imun. Anemia merupakan penyakit non-imun adalah anemia pada penyakit kronik ,anemia defisiensi besi, anemia sideroblastik, anemia pada penyakit ginjal, anemia indikasi obat, dan anemia sekunder terhadap penyakit lain ( misalnya anemia sel sabit ).

Tujuan Penelitian : Penelitian ini untuk mengetahui hubungan drajat aktivitas penyakit lupus eritematosus sistemik berdasarkan max-sledai dengan kadar hemoglobin pada penderita lupus eritematous sistemik di komunitas ODAPUS lampung tahun 2020.

Metode : Digunakan metode observasional analitik menggunakan pendekatan cross sectional. Subjek penelitian sebanyak 30 responden yang menggunakan teknik total sampling dari anggota komunitas ODAPUS Lampung dengan melakukan wawancara MEX-SLEDAl dan pengambilan sampel darah yang dilakukan pada bulan November 2019 s/d Februari 2020. Uji statistic menggunakan Fisher exact test.

Hasil : Dari 30 subjek penelitian didapatkan aktifitas penyakit berdasarkan MEXSLEDAI di atas rata - rata sebanyak 21 pasien (70\%). Dan hasil peneriksaan darah yaitu 18 pasien (60\%) yang Tidak anemia dan yang mengalami Anemia ada 12 pasien $(40 \%)$.

Kesimpulan : Terdapat hubungan bermakna antara derajat aktivitas penyakit Lupus Eritematosus Sistemik berdasarkan skor MEX-SLEDAI dengan Kejadian Anemia dengan $p$ value $=0.024$ berarti nilai $p$ value $\leq 0.05$.

Kata Kunci : LES; Kejadian Anemia; MEX-SLEDAI

\section{PENDAHULUAN}

$$
\text { LUPUS }
$$

Erythematosus

sistemic (LES) adalah penyakit autoimun multisistem kronik dengan spektrum manifestasi yang luas mulai dari keterlibatan kutaneus minor sampai dengan kerusakan organ yang berat (Ratnadi, Suega, \& Rena, 2014).

Suatu penyakit autoimun multisistem dengan manifestasi dan sifat yang sangat berubah-ubah. Secara klinis LES merupakan suatu penyakit kekambuhan dan sulit di perkirakan dengan awal manifestasi yang akut dan dapat menyerang ginjal, kulit, membran srosa, sendi dan jantung dan penyakit ini melibatkan susuan antibodi yang membingungkan (MD, PhD,\& N,2007) Insidensi tahunan SLE di Eropa sebesar 3,3 per 100.000 penduduk di Islandia dan 4,8 kasus per 100.000 penduduk di Swedia. Sedangkan di Amerika, insidesi LES telah diteliti dalam berbagai studi, dengan rentang antara 2,0 hingga 7,6 kasus per 100.000 penduduk. Di Onikawa, Jepang, sebuah penelitian mengidentifikasi 566 kasus baru dengan diagnosis SLE atau 3,0 kasus per 100.000 penduduk. Prevalensi LES di Amerika Serikat menunjukkan 
rentang 14,6 hingga 50,8 kasus per 100.000 penduduk.

Selain itu, terdapat studi epidemiologi SLE di Asia yang mencakup 24 negara didapatkan prevalensi SLE sebesar 30-50 kasus per 100.000 penduduk. Angka prevalensi tertinggi didapatkan di Sanghai, Cina dan tiga terendah pada India, Jepang, dan Saudi Arabia yakni 3,2-19,3.15 Belum terdapat data epidemiologi SLE yang mencakup semua wilayah Indonesia. Data tahun 2002 di RSUP Dr. Cipto Mangunkusumo (RSCM) Jakarta, didapatkan 1,4\% kasus SLE dari total kunjungan pasien di poliklinik reumatologi penyakit dalam, sementara di RS Hasan Sadikin Bandung terdapat 291 pasien LES atau $10,5 \%$ dari total pasien yang berobat ke poliklinik reumatologi selama tahun. Dalam 30 tahun terakhir, LES telah menjadi salah satu penyakit reumatik utama di dunia.(Hasanah, Maulidah Risky, 2016)

Anemia pada pasien LES bervariasi antara anemia penyakit kronis, anemia hemolitik, kehilangan darah, insufisiensi ginjal, infeksi, mielodisplasia, dan anemia aplastik. Yang sering terjadi anemia pada LES disebabkan supresi eritropoesis karena inflamasi yang kronis. Sangat mungkin terdapat anemia karena proses autoimun atau bukan, anemia yang didapat berupa anemia penyakit kronis, defisiensi besi dan diikuti anemia hemolitik autoimun (Hasanah R. M., 2016) anemia merupakan manifestasi yang paling sering terjadi diantara manifestasi klinis lainnya, Disusul dengan lupus nefritis yang terjadi pada $24,39 \%$ subjek.

Berdasarkan penelitian sebelumnya diketahui bahwa dari 10 subjek yang mengalami lupus nefritis, 9 diantaranya memiliki kadar $\mathrm{Hb}$ yang rendah. Kadar $\mathrm{Hb}$ berkisar antara 3.00-16.10 g/dl, dengan rerata $10.09 \pm 2.92 \mathrm{~g} / \mathrm{dl}$. Terdapat 29 (70.73\%) subjek dengan kadar $\mathrm{Hb}$ rendah dan 12 (29,30\%) subjek lainnya memiliki kadar $\mathrm{Hb}$ yang normal. Kadar $\mathrm{Hb}$ rendah terjadi pada 9 (31,00\%) subjek dengan tingkat keparahan ringan dan $20(69,00 \%)$ subjek dengan tingkat keparahan berat. Dua (16.70\%) subjek dengan tingkat keparahan penyakit berat dan 10 (83.30\%) subjek dengan tingkat keparahan penyakit ringan memiliki kadar $\mathrm{Hb}$ yang normal. Terdapat perbedaan kadar $\mathrm{Hb}$ antara pasien SLE ringan dengan pasien SLE berat. Didapatkan bahwa kadar $\mathrm{Hb}$ berhubungan dengan tingkat keparahan penyakit LES dan hubungan antara kadar $\mathrm{Hb}$ dengan tingkat keparahan penyakit LES bermakna secara statistik $(p<0.05)$. Semakin berat penyakit LES yang diderita, kadar $\mathrm{Hb}$ cenderung lebih rendah (Ratnadi., 2014)

Berdasarkan data World Health Organization (WHO), anemia adalah nilai kadar $\mathrm{Hb}<13 \mathrm{~g} / \mathrm{dL}$ pada laki-laki dan $<12 \mathrm{~g} / \mathrm{dL}$ pada wanita. Usia anak 6 bulan- 6 tahun dianggap anemia jika nilai kadar $\mathrm{Hb}<11 \mathrm{~g} / \mathrm{dL}$ dan usia antara 6-14 tahun kadar $\mathrm{Hb}$ sebesar < $12 \mathrm{~g} / \mathrm{dL}$ (Ardianti, et al., 2017)

Manifestasi hematologi terbanyak adalah anemia dengan proprosi 23,21\% sampel. Anemia yang dialami adalah anemia ringan dan juga beberapa pasien mengalami anemia hemolitik. Trombositopenia didapatkan pada $16,07 \%$ sampel. Trombositopenia pada pasien umumnya bersifat ringan $(>50.000 / \mathrm{mm} 3)$. Pada literatur sejalan dengan hasil penelitian dimana pasien SLE yang mengalami trombositopenia sebesar 7-30\%. Trombositopenia juga menunjukan tingkat keparahan dari SLE, manifestasi ini berkaitan dengan manifestasi lain seperti anemia hemolitik, dan gangguan 
ginjal. Tingkat keparahan trombositopenia dapat digunakan sebagai prognostic factor SLE. Manifestasi hematologi lainnya adalah leukopenia. Leukopenia dialami 14,28\% sampel. Leukopenia pada pasien SLE tidak sampai menyebabkan munculnya infeksi pada pasien. Hasil yang didapatkan lebih rendah dibandingkan dengan angka pada tinjauan pustaka yaiut 20-80\% pasien mengalami leukopenia (Darma , et al., 2018).

MEX-SLEDAI ini merupakan salah satu sistem penilaian yang praktis namun cukup akurat dalam pemantauan hasil terapi. Tidak digunakannya pemeriksaan labor atorium yang canggih dalam kriteria perbaikan dari pasien LES yang menyebabkan MEX-SLEDAl cocok digunakan terutama pada negaranegara berkembang. Meskipun begitu, penilaian respon klinis bersama-sama dengan pemantauan respon imun, diharapkan dapat memberikan hasil yang baik dalam penatalaksanaan pasien LES (Dhistiarinie, 2018).

\section{American}

Rheumatism

Association (ARA) mengajukan 11 kriteria untuk penegakan diagnosis LES yang diperbarui pada tahun 1997, dimana bila terdapat 4 kriteria maka diagnosis LES dapat ditegakkan. Perjalanan penyakit LES ini ditandai dengan remisi dan ekaserbasi sehingga, memerlukan pemantauan yang ketat akan aktivitas penyakitnya. Evaluasi aktivitas penyakit ini akan berguna sebagai panduan dalam pemberian terapi. Adapun untuk menilai aktivitas penyakit lupus maka digunakanlah skor SLEDAI (Systemic Lupus Erythematosus Disease Activity Index) selama perawatan dan follow up penderita LES setelah mendapatkan terapi dan untuk menilai derajat berat ringan nya aktivitas penyakit LES, sehingga diharapkan pengobatan kepada pasien LES akan berjalan lebih maksimal (Pradesta, et al., 2018).

Berdasaran penjelasan di atas, peneliti tertarik untuk meneliti lebih jauh lagi mengenai hubungan anemia dengan LES pada pasien LES di komunitas ODAPUS Lampung tahun 2020.

untuk mengetahui hubungan drajat aktivitas penyakit lupus eritematosus sistemik berdasarkan max-sledai dengan kejadian anemia pada penderita lupus eritematous sistemik di komunitas ODAPUS lampung tahun 2020

\section{METODELOGI PENELITIAN}

Penelitian ini menggunakan desain penelitian observational analytic untuk mencari hubungan antara variabel, Dengan maksud untuk melihat apakah terdapat hubungan antara LES dengankejadian anemia. Rencana penelitian ini menggunakan cross sectional dimana penelitian ini dilakukan $\mathrm{Di}$ komunitas ODAPUS lampung yang mana sebelumnya telah dinyatakan laik etik untuk melakukan penelitian sebelum pengambilan sampel. Sampel dalam penelitian ini sebanyak 31 Responden dengan Teknik pengambilan sampel secara Total sampling. Untuk menggumpulkan data dilakukan pengambilan sampel darah dengan spuit $5 \mathrm{ml}$ yang kemudian digunakan untuk dilakukan pemeriksaan Hemoglobin pada pasien penderita LES dan dilakukan wawancara dan pengisian kuisioner untuk penilaian MEX-SLEDAI kepada pasien LES yang tergabung di komunitas ODAPUS Bandar Lampung. Selanjutnya hasil data dari pengambilan sampel diolah dan di uji menggunakan statistic SPSS.

HASIL

Hasil dari penelitian ini didapatkan karakteristik usia pasien yang dikategorikan berdasarkan 
dekade menjadi 5 (lima) yaitu usia $\leq$ 10 tahun sebanyak 1 pasien $(3,3 \%)$, 11 - 20 tahun sebanyak 1 pasien $(3,3$ $\%), 21$ - 30 tahun sebanyak 10 pasien (33,3\%), 31 - 40 tahun sebanyak 11 pasien $(36,7 \%)$, > 40 tahun sebanyak 7 pasien $23,3 \%)$.

Hasil penelitian dan pengolahan karakteristik terlihat bahwasannya penderita Lupus Eritematosus Sistemik (LES) sebanyak 29 pasien $(96,7 \%)$ perempuan dan sebanyak 1 pasien $(3,3 \%)$ laki - laki. Juga dapat diketahui bahwa terdapat 11 pasien $(36,7 \%)$ yang telah menderita Lupus Eritematosus Sistemik (LES) selama > 5 tahun dan terdapat 19 pasien $(63,3$ $\%)$ yang telah menderita Lupus Eritematosus Sistemik (LES) selama < 5 tahun.

Untuk hasil dari pemeriksaan laboratorium hematologi didapatkan yang mengalami anemia sabanyak 12 pasien (40,0 \%) Lupus Eritematosus Sistemik (LES) dan yang tidak mengalami anemia sebanyak 18 pasien $(60,0 \%)$ Lupus Eritematosus Sistemik (LES). Untuk pemeriksaan leukosit didapatkan 4 pasien $(13,3 \%)$ Lupus Eritematosus Sisteik (LES) yang mengalami Leukopenia, dan 26 pasien $(86,7 \%)$ Lupus Eritematosus Sistemik (LES) tidak mengalami Leukopenia. Untuk trombosit diketahui bahwa 2 pasien $(6,7 \%)$ Lupus Eritematosus Sisteik (LES) yang mengalami Trombositopenia, dan 28 pasien $(93,3 \%)$ Lupus Eritematosus Sistemik (LES) tidak Trombositopenia. Selanjutnya untuk pemeriksaan urin di dapatkan hasil 1 pasien $(3,3 \%)$ kategori proteinuria +1 , di dapatkan 2 pasien $(6,7 \%)$ kategori proteinuria +2 , lalu 1 pasien $(3,3 \%)$ kategori proteinuria +3 , dan yang tidak mengalami proteinuria sebanyak 26 pasien $(86,7 \%)$. Untuk aktivitas skor MEX SLEDAI didapatkan hasil 2 pasien SLE $(6,7 \%)$ dalam fase remisi, terdapat 14 pasien SLE $(46,7 \%)$ dengan aktivitas penyakit ringan, dan 14 pasien SLE $(46,7 \%)$ dengan aktivitas penyakit sedang, dan tidak ada pasien dengan kategori aktivitas skor MEX-SLEDAI berat dan sangat berat di Komunitas ODAPUS Lampung.

Dari hasil penilaian tingkat depresi dan kualitas hidup bahwa responden yang tidak mempunyai gejala depresi yaitu sebanyak 14 orang $(47 \%)$, responden dengan gejala depresi ringan sebanyak 10 orang (33\%), responden dengan gejala depresi sedang sebanyak 5 orang (13\%), dan responden dengan gejala depresi berat yaitu 0 orang (0\%). Dan untuk kualitas hidup yang baik yaitu berjumlah 21 orang (70\%) sedangkan kualitas hidup yang buruk berjumlah 9 orang (30\%).

Untuk yang mengkonsumsi obat di ketahui bahwa terdapat 2 pasien $(6,7 \%)$ LES yang sudah tidak minum obat , 11 pasien ( $36,7 \%$ ) LES yang mengkonsumsi obat Methylprednisolone, 15 pasien $(50,0 \%)$ LES yang mengkonsumsi Methylprednisolone di tambah jenis obat lain ,dan 2 pasen $(6,7 \%)$ LES yang mengkonsumi obat jenios lain.

Distribusi karakteristik umum Pasien Lupus Eritematosus Sistemik di Komuntas ODAPUS Lampung.

$$
\mathbf{N}=\mathbf{3 0}
$$

\section{Karakteristik}

Jumlah Responden Persentase

(\%)

1. Usia
a. $\leq 10$ tahun
b. 11 - 20 tahun
1
$3,3 \%$
c. 21 - 30 tahun 

d. 31 - 40 tahun
11
$36,7 \%$
e. $>40$ tahun
7
$23,3 \%$

2. Jenis Kelamin
a. Laki - Laki
1
b. Perempuan
29
$3,3 \%$
$96,7 \%$

3. Diagnosis
a. > 5 tahun
$36,7 \%$
b. $<5$ tahun
$63,3 \%$

4. Obat
a. Tidak Minum Obat
$6,7 \%$
b. Methylprednisolone
$36,7 \%$
c. Methylprednisolone +
$50,0 \%$ Jenis Obat Lain
d. Jenis Obat Lain
$6,7 \%$

5. Kadar Hemoglobin
a. Anemia
$40,0 \%$
b. Tidak Anemia
$60,0 \%$

6 . Leukosit
a. Leukopenia
4
$13,3 \%$
b. Tidak Leukopenia
26
$86,7 \%$

7 . Trombosit
a. Trombositopenia
2
$6,7 \%$
b. Tidak Trombositopenia 28
$93,3 \%$

8 . Proteinuria
a. Negatif
b. +1
c. +2
d. +3

$86,7 \%$

1

2

$3,3 \%$

$6,7 \%$

$3,3 \%$

9. Skor MEX- SLEDAI
a. Remisi
$6,7 \%$
b. Ringan
$46,7 \%$
c. Sedang
d. Berat
0
e. Sangat Berat
0
$46,7 \%$
$0 \%$
$0 \%$

10 . Tingkat Depresi
a. Tidak ada gejala
$47 \%$
b. Depresi ringan
10
$33 \%$
c. Depresi sedang
5
d. Depresi berat
$13 \%$
$0 \%$

11. Kualitas Hidup
a. Baik
21
$70 \%$
b. Buruk 
Karakteristik aktivitas penyakit berdasarkan skor MEXSLEDAI pada penderita LES

\begin{tabular}{|c|c|c|}
\hline $\begin{array}{l}\text { Aktivitas berdasarkan skor MEX- } \\
\text { SLEDAI }\end{array}$ & Frekuensi & Persentase \\
\hline Remisi & 2 & $6,7 \%$ \\
\hline Ringan & 14 & $46,7 \%$ \\
\hline Sedang & 14 & $46,7 \%$ \\
\hline Berat & 0 & $0 \%$ \\
\hline Sangat berat & 0 & $0 \%$ \\
\hline Total & 30 & $100 \%$ \\
\hline
\end{tabular}

dengan aktivitas MEX-SLEDAI kategori remisi sebanyak 2 pasien $(6,7 \%)$ dengsn aktivitas MEX-SLEDAI kategori ringan sebanyak 14 pasien $(46,7 \%)$, dan dengan aktivitas MEXSLEDAI kategori sedang sebanyak 14 pasien $(46,7 \%)$. Karena banyaknya kategori untuk derajat aktivitas penyakit lupus etitematosus sistemik Karakteristik aktivitas penyakit berdasarkan skor MEX-SLEDAI pada penderita LES dalam penelitian MEX-SLEDAI, maka penulis membagi menjadi 2 kategori yaitu diatas rata - rata dan di bawah rata - rata. Yang mana rata - ratanya adalah hasil dari rerata jumlah skor seluruh responden, tujuan dari pembagaian kategori di atas rata rata dan di bawah rata - rata yaitu untuk mempermudah proses analisi.
Aktivitas berdasarkan skor MEX-

$$
\text { SLEDAI }
$$

\begin{tabular}{ccc}
\hline Di bawah rata - rata & 9 & $30 \%$ \\
Di atas rata - rata & 21 & $70 \%$ \\
\hline Total & 30 & $100 \%$ \\
\hline
\end{tabular}

2. HEMOGLOBIN

Karakteristik pasien LES yang mengalami Anemia

\begin{tabular}{lll}
\multicolumn{1}{c}{ Pemeriksaan Hemoglobin } & Frekuensi & Persentase \\
\hline Anemia & 12 & $40 \%$ \\
Tidak Anemia & 18 & $60 \%$ \\
\hline Total & 30 & $100 \%$ \\
\hline
\end{tabular}

ketahui untuk frekuensi lupus eritematosus sistemik (LES) di
Frekuensi Persentase

dapatkan pasien yang mengalami Anemia sebanyak 12 pasien (40\%) 
dan yang tidak anemia sebanyak 18 pasien $(60 \%)$.

Analisis bivariat

Hubungan Derajat Aktivitas Penyakit Lupus Eritematosus sistemik berdasarkan skor MEX -SLEDAI dengan kejadian anemia

\begin{tabular}{|c|c|c|c|c|c|c|c|c|c|}
\hline \multirow{3}{*}{ MEX-SLEDAI } & \multicolumn{5}{|c|}{ Anemia } & & \multirow{3}{*}{$\begin{array}{c}P \\
\text { Value }\end{array}$} & \multirow{3}{*}{$\begin{array}{l}\text { Odds } \\
\text { Ratio }\end{array}$} & \multirow{3}{*}{$\mathrm{Cl} 95 \%$} \\
\hline & \multicolumn{2}{|c|}{$\mathrm{Ya}$} & \multicolumn{2}{|r|}{ Tidak } & \multicolumn{2}{|c|}{ Total } & & & \\
\hline & $\mathbf{N}$ & $\%$ & $\mathbf{N}$ & $\%$ & $\mathbf{N}$ & $\%$ & & & \\
\hline $\begin{array}{c}\text { Di Bawah Rata - } \\
\text { rata } \\
\text { Di Atas Rata - rata }\end{array}$ & $\begin{array}{l}9 \\
9\end{array}$ & $\begin{array}{l}90 \\
45\end{array}$ & $\begin{array}{c}1 \\
11\end{array}$ & 1055 & $\begin{array}{l}10 \\
20\end{array}$ & $\begin{array}{l}100 \\
100\end{array}$ & 0.024 & 0.091 & $0.010-0.859$ \\
\hline Total & 18 & 60 & 12 & 40 & 30 & 100 & & & \\
\hline
\end{tabular}

menunjukan bahwa dari 10 pasien LES (100\%) dengan derajat aktivitas MEX-SLEDAI di bawah rata - rata ada 9 pasien $(90 \%$ ) yang tidak mengalami Anemia, dan 1 pasien (10\%) yang aktivitas MEX-SLEDAI di bawah ratarata mengalami Anemia. Sedangkan dari 20 pasien LES (100 \%) yang memiliki derajat aktivitas MEXSLEDAI di atas rata - rata, sebanyak 9 pasien LES (45 \%) yang tidak mengalami Anemia, dan sebanyak 11 pasien LES (55 \%) mengalami Anemia. Hasil Fisher exact test didapatkan $p$ value $=0.024$ berarti nilai $p$ value $\leq 0.05$, maka $\mathrm{HA}$ diterima, yang berarti terdapat hubungan yang bermakna antara derajat aktivitas penyakit Lupus Eritematosus Sistemik berdasarkan skor MEX-SLEDAl dengan kejadian anemia.

\section{PEMBAHASAN}

Hubungan Derajat Aktivitas Penyakit Lupus Eritematosus Sistemik Berdasarkan Skor MEXSLEDAI Dengan Kejadian Anemia Hasil uji Fisher exact test berdasarkan seperti tabel 4.5. terihat bahawa terdapat hubungan bermakna antara derajat aktivitas penyakit Lupus Eritematosus Sistemik berdasarkan skor MEXSLEDAI dengan Kadar Hemoglobin dengan $p$ value $=0.024$ berarti nilai $p$ value $\leq 0.05$, maka HA diterima, yang berarti terdapat hubungan yang bermakna antara derajat aktivitas penyakit Lupus Eritematosus Sistemik berdasarkan skor MEXSLEDAl dengan kejadian anemia.Pada $50 \%$ penderita lupus eritematosus sistemik ditemukan adanya anemia. Anemia adalah berkurangnya atau penurunan kadar hemoglobin pada perempuan, < 12 $\mathrm{g} / \mathrm{dl}$ dan < $13 \mathrm{~g} / \mathrm{dl}$ pada laki-laki (Amaylia, 2008).

Penelitian ini sejalan dengan penelitian Ratnadi di Denpasar, Bali yang menerangkan bahwa 70,73\% subjek memiliki kadar $\mathrm{Hb}$ yang rendah. Persentase ini lebih tinggi dibandingkan dengan hasil pada studi yang dilakukan oleh Rouf (dalam Ratandi, et al., 2014).Kadar $\mathrm{Hb}$ pada penelitian ini berhubungan dengan tingkat keparahan penyakit LES dan hubungan tersebut bermakna secara statistik $(p<0.05)$. Penderita LES dengan tingkat keparahan penyakit berat cenderung memiliki kadar $\mathrm{Hb}$ yang rendah dan 
penderita LES dengan tingkat keparahan SLE ringan sangat sedikit yang mengalami penurunan kadar $\mathrm{Hb}$. Hal ini mungkin disebabkan karena pada penyakit LES dengan tingkat keparahan yang masih ringan, antibodi yang berperan dalam patogenesis SLE belum menyerang sistem hematologi maupun sistem lain yang berhubungan dengan eritropoiesis seperti ginjal. Penurunan kadar $\mathrm{Hb}$ pada penderita LES dapat disebabkan oleh karena faktor imun maupun nonimun, meskipun pada awalnya diduga anemia pada LES terutama disebabkan oleh antibodi antieritrosit yang merusak eritrosit (Ratandi, et al., 2014.).

Dalam teori dikatakan bahwa anemia ditemukan pada $50 \%$ pasien LES, berbagai mekanisme berperan dalam terjadinya anemia, termasuk inflamasi, insufisiensi renal, kehilangan darah, intake yang kurang, obat-obatan, hemolisis, infeksi, hipersplenisme, mielofibrosis, mielodisplasia, dan adanya patogenesis autoimun pada anemia aplastik. Penyebab anemia yang sering pada LES adalah tertekannya eritropoesis akibat inflamasi kronik,merupakan jenis yang paling sering (60 - 80\%)(Evalina, 2017).

\section{KESIMPULAN}

Setelah dilakukan penelitian tentang hubungan derajat aktivitas penyakit lupus eritematosus sistemik berdasarkan skor MEX-SLEDAl dengan Kejadian Anemia Komunitas Odapus Lampung, dapat disimpulkan bahwa Subjek penelitian terbanyak berdasatkan MEX-SLEDAl yaitu dengan aktifitas penyakit di atas rata - rata sebanyak 21 pasien $(70 \%)$. Subjek penelitian terbanyak berdasarakan hasil pemeriksaan hemoglobin sabnyak 18 pasien $(60 \%)$ tidak anemia dan terdapat hubungan yang signifikan antara derajat aktivitas lupus eritematosus sistemik berdasarkan skor MEX-SLEDAI dengan kejadian anemia.

\section{DAFTAR PUSTAKA}

Ardianti, D., Triyani, Y., Afgani, A., \& Herawati , R. (2017). Gambaran Morfologi Apusan Darah Tepi Dan Karakteristik Pasien Anemia Di Laboratorium Rs Al-Islami Priode Juni-Desember 2016 (Vol. Vol. 1). Bandung: Fakultas Kedokteran Universitas Islam Bandung.

Asih, R. F. (2015). Faktor-Faktor Yang Berhubungan Dengan Kelelahan Pada Pasien Systemic Lupus Erithematosus (LES). Semarang: Jurnal Fakultas Ilmu Keolahragaan Universitas Negeri Semarang.

Darma , N. A., Sartuti, T. I., \& Kurniari, P. S. (2018). Karakteristik Manifestasi Klinis Pasien Sistemik Lupus Eritematosus Di Poliklinik Rematologi Rsup Sanglah Periode Juni-September 2018 (Vol. Vol. 9). Denpasar: Fakultas Kedokteran Universitas Udayana .

Dhistiarinie, P. A. (2018). Pengaruh Kortikosteroid Pulse Dose Terhadap Jumlah Sel Limfosit T CD4+, Kadar Sel T Regulator Interleukin -2 Dan Nilai MexSledai Pada Pasien Lupus Eritematosus Sistemik - Padang : Fakultas Kedokteran Universitas Andalas.

Djoerban, z. t.thn.. Kelainan Hematologi Pada Lupus Eritematosus Sistemik. Buku Ajar Ilmu Penyakit Dalam Jilid III Edisi VI.

Evalina, R. (2017). Kelainan Darah Pada Systemic Lupus Erythematosus. Medan 
:Jurnal Fakultas Kedokteran Sumatra Utara .

Ghrahani, R., Sapartini, G., \& Satiabudiawan, B. (2015). Pola Antibodi Antinuklear Sebagai Faktor Resiko Keterlibatan Sistem Hematologi Lupus Eritematosus Sistemik Pada Anak (Vol. Vol. 47). Bandung: $\quad$ Fakultas Kedokteran Universitas Padjajaran.

Hasanah , R. M. (2016). Hubungan Tingkat Aktivitas Penyakit Dengan Kecenderungan Kejadian Depresi Pada Pasien Lupus Eritematosus Sistemik. Semarang: Jurnal Fakultas Kedokteran Universitas Diponegoro .

Hidayati, F. (2014). Ketabahan Dan Kecendrungan Depresi Pada Penderita Lupus (Vol. Vol. 6). Semarang: Fakultas Psikologi Universitas Diponegoro.

Kiswari , D. R. (2014). Buku Hematologi \& Transfusi . Semarang: Buku Hematologi \& Transfusi Erlangga.

Irdayanti, (2017). Identifikasi Kadar Hemoglobin ( $\mathrm{Hb})$ Pada Ibu Hamil Trimester I,II Dan III Terhadap Kejadian Anemia Di Puskesmas Poasia, Kendari :Jurnal Politehnik Kesehatan Kendari.

Ladyani, F. (2019). Bubungan Antara Kadar Hemoglobin Dengan Kelelahan Pada Pasien Systemic Lupus Erytematosus Pada Komunitas Odapus Lampung. Lampung: Fakultas Kedokteran, Universitas Malahayati.

Lestari, I. P., Lepoeto, N. I., \& Almurdi. (2017). Hubungan Konsumsi Zat Besi Dengan Kejadian Anemia Pada Murid
Smp Negeri 27 Padang . Padang,

Barat:Jurnal Sumatra Andalas.

Md, V. K., Phd, M. M., \& N, R. (2007). Buku Ajar Patologi Robbins Vol. 1 Edisi 7. Jakarta: Egc.

Muthusamy, V. (2017). Systemic Lupus Erythematous. Bali: Fakultas Kedokteran Universitas Udayana.

Novita, C. A. (2018). Hubungan Derajat Anemia Pada Pasien Dengan Gagal Ginjal Kronik Terhadap Perdarahan Retina - Medan: Jurnal Fakultas Kedokteran Universitas Sumatera Utara .

Pranandaru, H. (2019). Septik Arthritis Genu Dextra Pada Pasien Dengan Sostemik Lupus Eritematosus. Surakarta:Jurnal Fakultas Kedokteran Universitas Sebelas Maret.

Pradesta, R., Liana, P., \& Haryadi, K. (2018). Hubungan Hasil Labolatorium Pasien Lupus Eritematosus Sistemik Dengan Skor Sledai Di Rsup Dr Mohammad Hoesin Palembang (Vol. Vol.4). Palembang: Jurnal Fakultas Kedokteran Universitas Sriwijaya.

Ratnadi, P. C., Suega, K., \& Rena, N. (2014). Hubungan Antara Kadar Hemoglobin Dengan Tingkat Keparahan Penyakit Pasien Systemic Lupus Erithematosus Di Rsup Sanglah. Denpasar: Jurnal Fakultas Kedokteran Universitas Udayana .

Resmana, F R. (2018). Faktor Risiko Kejadian Penyakit Systemic Lupus Erythematosus (SLE) Di Rsup Dr. M. Djamil Padang Tahun 2017. Padang :Jurnal Fakultas Kesehatan 
Masyarakat Universitas Andalas .

Saleh, A., Kurniati, N., \& Syarif, H. B. (2014). Penilaian Aktivitas Penyakit Lupus Eritematosus Sistemik Dengan Skor Sledai Di Departemen Ilmu Kesehatan Anak Rscm. Jakarta : Jurnal Fakultas Kedokteran Universitas Indonesia.

Savira, Maya;. (2011). luaran Kehamilan Dengan Sistemik Lupus Eritematosus. Pekanbaru,Riau: Jurnal Fakultas Kedokteran Universitas Riau.

Suarjana, I. (2014). Ilmu Penyakit Dalam, Imunopatogenesis Lupus Eritematosus Sistemik (Vol. Edisi VI). Jakarta: interna publishing.

Wahyuni, S. (2018). Peran Imunitas Humoral Pada Penyakit Systemic Lupus Erythematosus (LES). Jurnal Fakultas Kedokteran Universitas Malikussaleh.

Yazid, A. F. (2019). Prevalensi Kelainan Hematologi Pada Pasien Lupus Eritematosus Sistemik Di Rsup Dr. M. Djamil . Padang: Jurnal Fakultas Kedokteran Universitas Anda. 